\title{
APLIKASI MENGENAL CANDI PADA PELAJARAN SEJARAH UNTUK SEKOLAH DASAR KELAS IV DENGAN VIRTUAL REALITY
}

\author{
Muslih \\ Tehnik Informatika, Universitas Dian Nuswantoro, Semarang \\ muslih@dsn.dinus.ac.id
}

\begin{abstract}
Abstrak
Dalam proses pembelajaran saat ini, pemanfaatan teknologi berbasis aplikasi dan internet adalah keharusan. Pembelajaran melalui jaringan internet untuk mendukung Kegiatan Belajar Mengajar juga sudah banyak dilakukan. Kegiatan belajar mengajar adalah proses transfer ilmu dari guru sebagai pengajar kepada siswa sebagai objek dalam mempelajari sebuah materi pelajaran. Guru dan siswa harus dapat berinteraksi secara timbal balik untuk saling mempengaruhi dan dipengaruhi satu sama lainya. Salah satu pelajaran yang cukup sulit dipahami oleh siswa kelas empat sekolah dasar adalah pelajaran sejarah. Pelajaran sejarah kurang dapat dipahami karena kurang menarik dalam proses pembelajarannya, terutama pokok bahasan tentang candi. Kegiatan belajar mengajar yang seperti itu membutuhkan media dengan memanfaatkan teknologi pembelajaran dengan memanfaatkan aplikasi interaktif. Website dan aplikasi mobile dipandang sangat baik untuk mendukung pembelajaran elektronik digital $(e-$ learning). Salah satu teknologi yang dapat dimanfaatkan adalah teknologi virtual reality. Metode Penelitian yang digunakan adalah pendekatan kuantitatif dengan teknik wawancara dan studi literatur. Untuk pengembangan aplikasi menggunakan metode software Development Life Cycle $(S D L C)$. Aplikasi pembelajaran Virtual Reality ini membuat siswa lebih mudah. Aplikasi ini mendukung e-learning dengan memiliki kelebihan dapat belajar dimanapun dan kapanpun dengan konten-konten yang berupa text, image, serta video.
\end{abstract}

Kata Kunci : aplikasi, virtual reality, candi, sekolah dasar

\begin{abstract}
In today's learning process, the use of application-based technology and the internet is imperative. Learning through internet networks to support Teaching and Learning Activities has also been widely practiced. Teaching and learning activities are the processes of transferring knowledge from the teacher as a teacher to students as an object in learning a subject matter. One of the subjects that are quite difficult to understand for fourth-grade elementary school students is history lessons. History lessons are less understandable because they are less interested in the learning process, especially the subject of temples. Such teaching and learning activities require media by utilizing learning technology by utilizing interactive applications. Websites and mobile applications are considered very good for supporting digital electronic learning (e-learning). One of the technologies that can be utilized is virtual reality technology. The research method used is a quantitative approach with interviews and literary techniques. For application development using the Software Development Life Cycle (SDLC) method. This Virtual Reality learning application makes students easier. This application supports e-learning with the advantage of being able to learn anywhere and anytime with content in the form of text, images, and videos.
\end{abstract}

Keywords: applications, virtual reality, temples, primary schools 


\section{PENDAHULUAN}

Revolusi Industri 4.0 yang mengkolaborasikan teknologi otomatis dan teknologi cyber yang didasarkan dari teknologi informasi dalam pengaplikasianya. Terdapat lima pilar teknologi dalam membangun dan mengembangkan industri digital saat ini, yaitu Internet of Things, Big Data, Artificial Intelligence, Cloud Computing dan Additive Manufacturing (Rizkinaswara, 2020). Internet of Things (IOT) adalah sebuah sistem yang memanfatkan perangkat komputasi, mekanis, dan mesin digital dalam satu keterhubungan (interrelated connection). Salah satu pilar yang mendukung untuk proses pembelajaran saat ini adalah pilar Cloud Computing, dimana pemanfaatan teknologi berbasis internet dapat dijadikan sebagai pusat pengelolaan data dan aplikasi. User diberikan hak akses (login) untuk memanfaatkan cloud agar dapat mengkonfigurasi peladen (server) melalui jaringan internet untuk mendukung Kegiatan Belajar Mengajar (KBM).

Dalam pemanfaatan teknologi terutama di era Revolusi Industri 4.0 dalam proses KBM, ada unsur dasar yang sangat penting adalah metode mengajar dan konten pembelajaran yang sering menjadi kendala. Hal ini dipandang dari perbedaan antara konten pembelajaran yang disampaikan oleh pendidik. Salah satu konten pembelajaran yaitu pembelajaran melalui digitalisasi yang sekarang dapat diakses dengan mudah di mana pun selama ada akses internet yang memadai dan tentunya stabil. Pembelajaran digital juga merupakan salah satu inovasi pembelajaran dengan menciptakan proses interaktif dengan metode yang digunakan literasi pemrosesan data elektonik digunakan untuk merubah data informasi yang lebih bermanfaat dengan objek mentah dan belum di proses sehingga dapat diambil data informasi yang sekiranya tepat untuk digunakan (Nana \& Surahman, 2019).

Teknologi dalam pembelajaran digital tidak bisa lepas dari pesatnya perkembangan hardware terutama teknologi smartphone dan operating system yang dipakai seperti android, IOS, Tizen, KaiOS, dan lain-lain. Ditunjang juga dengan para developer aplikasi yang kreatif dan aktif dalam pembuatan aplikasi sehingga dapat mempermudah pengguna aplikasi dalam mengakses pembelajaran digital secara instan dan efisien. Aplikasi adalah penggunaan atau penerapan perangkat lunak yang dibuat untuk membantu dan mempermudah pengguna dalam melaksanakan tugas tertentu (Pane, Zamzam, \& Fadillah, 2020). Selain itu ada kebutuhan masyarakat dalam pemanfaatan teknologi untuk media pembelajaran digital yang sering digunakan dalam penyampaian konten multimedia secara instan dan efisien mulai dari media teks, suara, gambar, hingga sampai merambah 3D modeling dan video. Multimedia juga digunakan sebagai media pembelajaran interaktif mengimplementasikan dengan menggunakan aplikasi berbasis website dan aplikasi berbasis android karena manfaatnya lebih memudahkan saat melakukan proses KBM. Sedangkan aplikasi berbasis website merupakan keseluruhan dari berbagai beranda dan halaman web yang berasal di dalam sebentuk domain dan server yang memuat informasi yang dibangun atas berbagai halaman saling berhubungan (Yuhefizar, Mooduto, \& Hidayat, 2009). 
Salah satu masalah yang dialami dalam pembelajaran secara digital dan daring (elearning) adalah pembelajaran siswa sekolah dasar kelas IV. Siswa sekolah dasar kelas IV memiliki kesulitan dalam mempelajari mata pelajaran sejarah. Mata pelajaran sejarah sulit untuk mereka pahami karena siswa kesulitan untuk menghafal banyak materi. Mata pelajaran sejarah juga dianggap kurang menarik dan menyenangkan dalam pembelajarannya (Alfian, 2011). Guru hanya memberikan materi ajar dan siswa dituntut untuk menghafal saja. Siswa hanya berpikir bahwa pelajaran sejarah adalah pelajaran menghafal tanggal dan nama saja. Materi pelajaran sejarah yang diajarkan juga dianggap terlalu banyak. Padahal esensi dari belajar sejarah adalah menggali nilai-nilai dalam peristiwa sejarah dan belajar bagaimana tokoh sejarah menghadapi hidup dan membuat sejarah. Selain itu pendidikan sejarah juga mengasah kemampuan mental siswa dalam menggunakan dan memanfaatkan secara reflektif pengalaman historis untuk memahami dan menyikapi secara kritis berbagai fenomena yang dihadapi pada masa kini (Purwanta, 2019).

Salah satu materi yang sulit dipahami oleh siswa SD kelas IV dalam belajar sejarah adalah materi tentang peninggalan sejarah khususnya materi Candi. Materi candi ini berada pada buku Ilmu Pengetahuan Sosial 4 Untuk Kelas IV SD dan MI (Sutoyo \& Agung, 2009) dan buku (Kementerian Pendidikan dan Kebudayaan, 2014). Materi ini membahas tentang peninggalan sejarah, salah satunya adalah candi. Indonesia yang memiliki luas wilayah 1,905 juta $\mathrm{km}^{2}$ mempunyai banyak benda-benda peninggalan bersejarah terutama candi. Candi adalah bangunan kuno terbuat dari batu. Candi digunakan sebagai tempat pemujaan, ibadah atau makam raja-raja. Nilai penting yang mendasari pembelajaran sejarah candi tidak dapat hanya dilihat melalui keindahan bangunanbangunannya saja, melainkan perannya dalam membentuk kebudayaan masyarakat pada saat itu hingga saat ini bahkan pada masa mendatang. Candi juga menyimpan nilainilai luhur dibalik keindahan arsitekturalnya. Nilai-nilai luhur tersebut terdapat pada bentuk bangunan dan relief yang ada di dalamnya. Jumlah candi di Indonesia diperkirakan berjumlah ribuan. Untuk dapat mengenali candi yang banyak jumlahnya, siswa sekolah dasar kelas IV membutuhkan sebuah media yang dapat mempelajarinya dengan mudah dan menyenangkan. Aplikasi mengenal candi pada pelajaran sejarah untuk sekolah dasar kelas IV dengan virtual reality adalah solusi dari permasalahan ini. Penelitian ini dilakukan karena belum ada yang membuat aplikasi virtual reality seperti ini sebelumnya. Media yang sudah ada adalah menggunakan media buku pop up (Sugiarti, 2017) dan augmented reality (Barkah \& Agustina, 2017).

\section{METODE PENELITIAN}

Metode penelitian yang digunakan untuk memunculkan variabel-variabel model dalam sistem pembelajaran candi untuk kelas IV Sekolah Dasar ini adalah pendekatan kuatitatif dengan teknik wawancara. Wawancara dilakukan kepada klien yaitu lembaga pengembangan multimedia konten mobile pendidikan, Balai Pengembangan Multimedia Pendidikan dan Kebudayaan (BPMP) Jawa tengah. Disamping dengan metode wawancara metode lain yang digunakan adalah observasi dan literatur dari buku-buku teks, diktat yang mendukung data tersebut. Untuk pengembangan aplikasi sendiri menggunakan metode software Development Life Cycle (SDLC) yang dikenal 
dengan nama system waterfall. Metode waterfall merupakan suatu metode dalam pengembangan software dimana pengerjaannya harus dilakukan secara berurutan yang dimulai dari tahap perencanaan konsep, pemodelan (design), implementasi, pengujian dan pemeliharaan (Dwanoko, 2016).

\section{Requirements \\ analysis and \\ definition}

System and software design

Implementation And Unit Testing

\section{Integration and \\ system testing}

\section{Operation And}

Maintenance

Gambar 1. Metode software Development Life Cycle (SDLC)

[Sumber : Dwanoko, 2016]

Sedangkan testing untuk melihat dampak ergonomi dari aplikasi yang dipakai oleh pengguna (user) dilakukan dengan mengujicobakan pada siswa kelas IV SD Patemon 02 Semarang. Kerangka pemikiran dari penelitian ini adalah

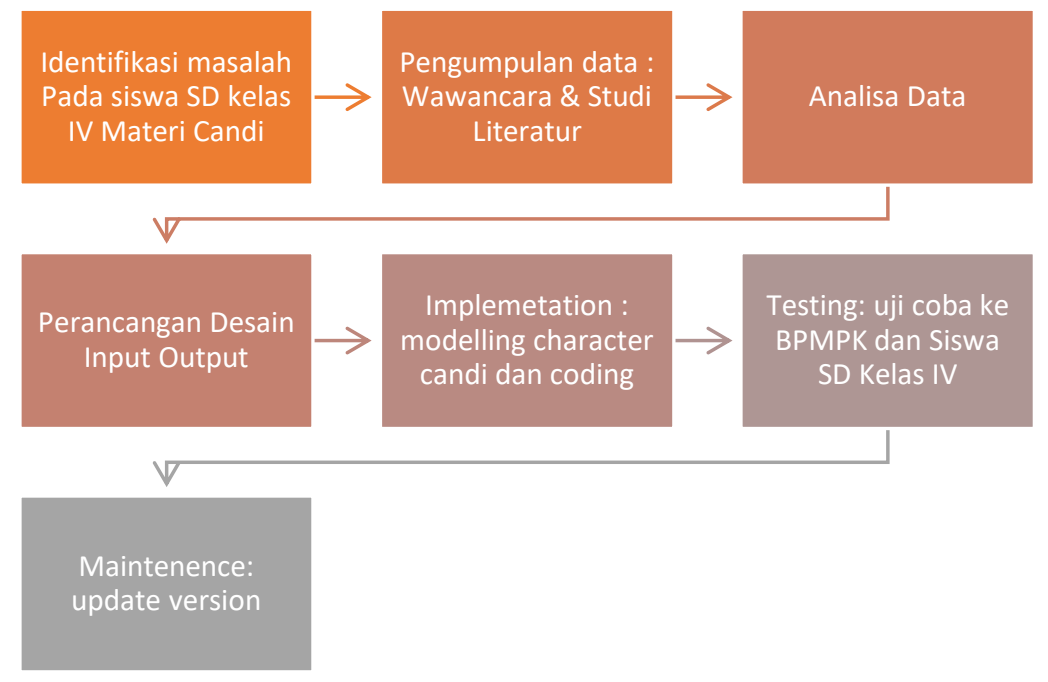

Gambar 2. Kerangka pemikiran

[Sumber : Dokumentasi penulis, 2020]

\section{HASIL DAN PEMBAHASAN}

Penelitian dilakukan menggunakan metode pengembangan sistem waterfall dengan tahapan-tahapan dalam kerangka pemikiran seperti di atas. 


\subsection{Requirements Analysis and Definition}

Analisa kebutuhan sistem, pengumpulan data dengan wawancara dengan lembaga pengembangan multimedia konten mobile pendidikan Balai Pengembangan Multimedia Pendidikan dan Kebudayaan serta solusi sistem yang digunakan dengan Virtual Reality.

\subsection{System and Software Design}

Perancangan context diagram dan entity relationship diagram untuk menjelaskan mengenai alur sistem yang dibuat dalam model pembelajaran ini. Aplikasi dirancang mulai dari goal atau hasil yang diharapkan dari aplikasi ini sampai dengan desain user interface dan user experience.

\subsection{Implementation And Unit Testing}

Pada tahap ini, membuat sistem dengan modelling character dengan software pengolah tiga dimensi yaitu blender dan membuat aplikasi dalam website dan mobile.

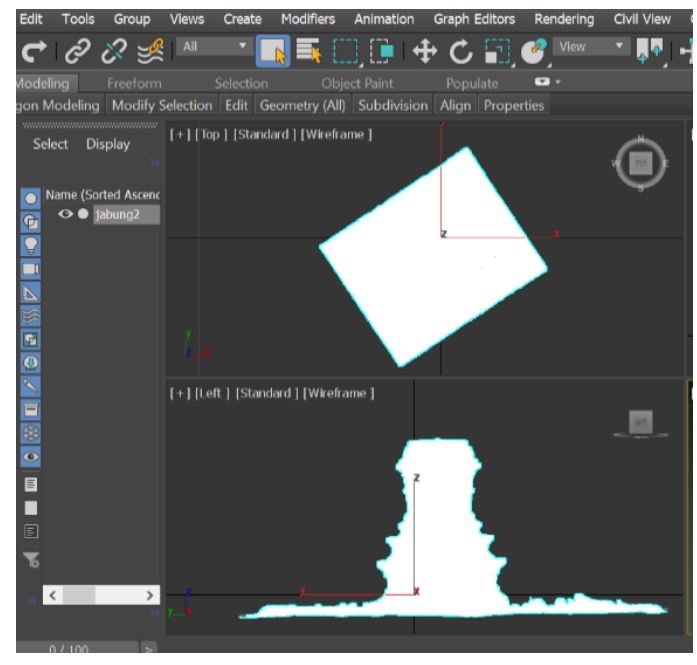

Gambar 3. Proses Modeling 3D Candi

[Sumber : Dokumentasi penulis, 2020]

a. Ikon dalam aplikasi mobile

Tampilan desain untuk pilihan ikon link aplikasi mobile Candi dengan pilihan ikon buku. Untuk nama aplikasi ini adalah Aplikasi Mobapp Candi.

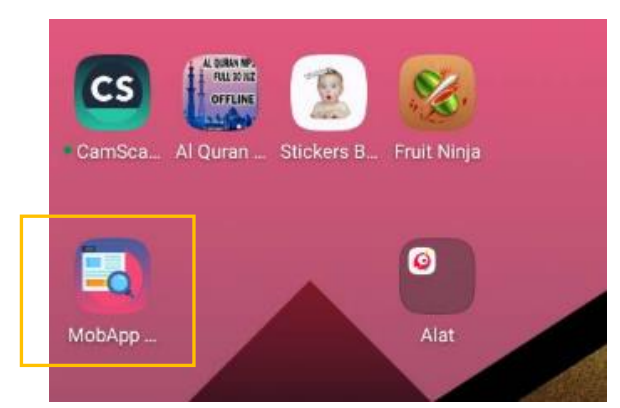

Gambar 4. Ikon Menu Aplikasi Mobile [Sumber : Dokumentasi penulis, 2020] 
b. Menu pembelajaran

Bentuk candi-candi dimunculkan sesuai dengan relief yang ada pada materi buku sejarah, user dalam hal ini siswa dapat mengclick gambar untuk melihat materi detailnya.

$\equiv$ MobApp candi $\quad$ :

PILIHAN MENU VR BETA VR

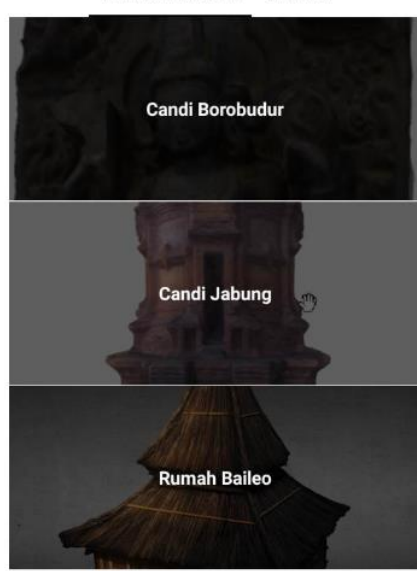

Gambar 5. Menu Materi Candi

[Sumber : Dokumentasi penulis, 2020]

c. Detail materi Belajar

Jika menu ini dapat dilihat detail materi dari candi yang dipilih user, yaitu informasi, arsitektur serta posisi letak dari candi tersebut.

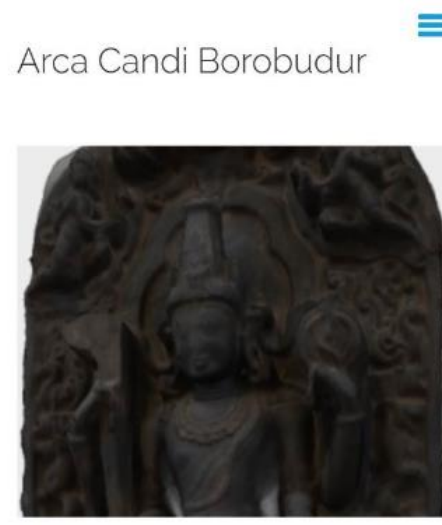

Informasi

Arsitektur: Stupa Dan Candi dengan

piramida berundak dari susunan

Kota: Magelang

Provinsi: Jawa Tengah

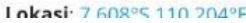

Gambar 6. Menu Detail Materi Candi

[Sumber : Dokumentasi penulis, 2020] 


\section{d. Soal Latihan}

Setelah siswa melakukan pembelajaran dengan materi yang ditampilkan, siswa dapat mengerjakan soal-soal latihan sebagai indikator ketuntasan belajar lulus ataupun tidak dari siswa tersebut .

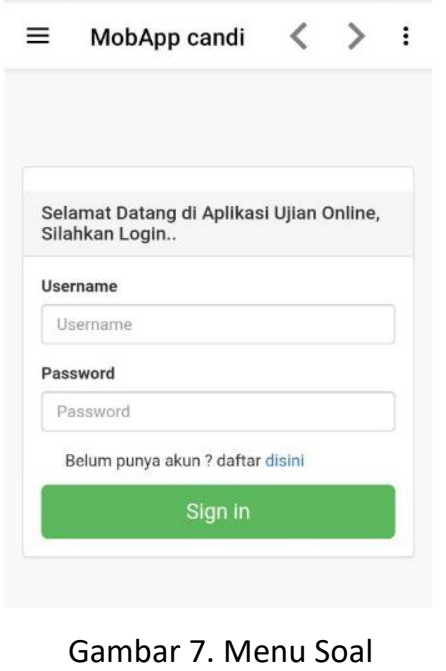

[Sumber : Dokumentasi penulis, 2020]

e. About

Tampilan splash screen dari version dan pembuat aplikasi ini.

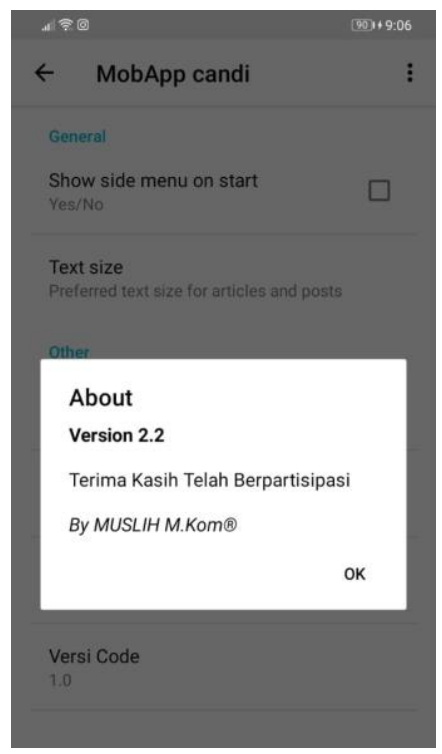

Gambar 8. Tampilan Menu About [Sumber : Dokumentasi penulis, 2020]

\subsection{Integration and System Testing}

Function dan procedure untuk pengujian bentuk 3D model Candi sesuai dengan yang ditangkap oleh sistem atau tidak. 


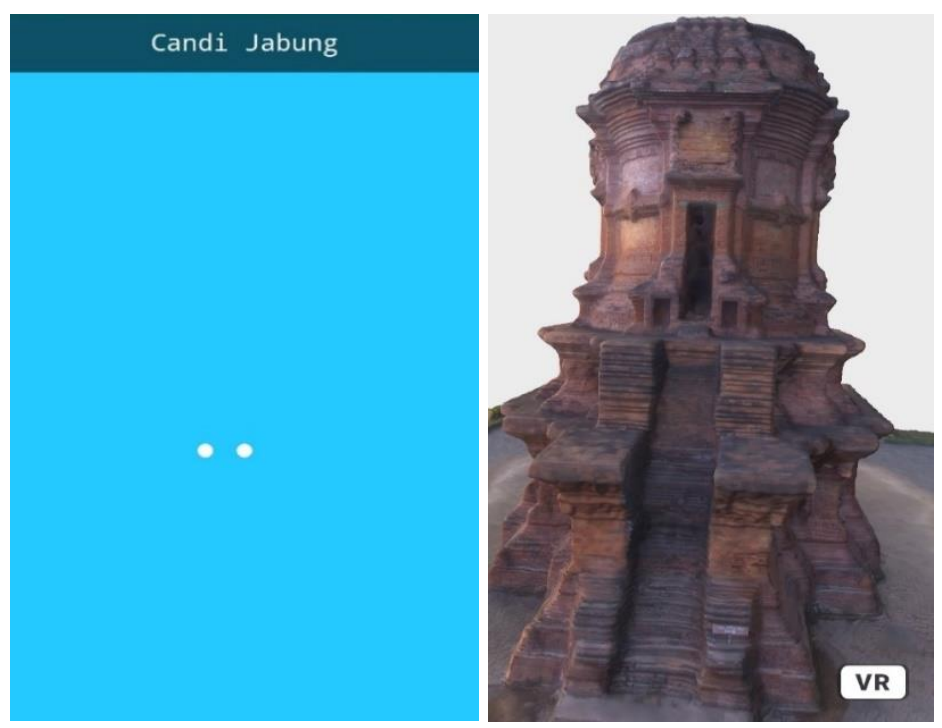

Gambar 9. Tampilan virtual reality

[Sumber : Dokumentasi penulis, 2020]

\subsection{Operation and Maintenance}

Dari feedback pengguna (user) dan pengelola ( $a d m i n$ ) dapat digunakan sebagai masukan pengembangan sekaligus kontrol kekurangan-kekurangan dari aplikasi ini. Pengujian dilakukan kepada guru dan siswa siswa kelas IV SD Patemon 02 melalui aplikasi video daring Zoom Meet. Hal ini dipilih karena selama pengujian masih adanya pandemik Covid 19. Hasil dari pengujian ini dapat dilihat bahwa siswa menjadi sangat tertarik dengan aplikasi yang dihasilkan. Siswa merasa materi yang disampaikan menjadi lebih jelas dan menyenangkan. Mereka dapat melihat bentuk Candi secara lebih nyata. Dari pihak Guru juga merasa terbantu dengan aplikasi yang dihasilkan. Guru dapat mengontrol materi yang diberikan kepada siswa dengan lebih baik lagi.

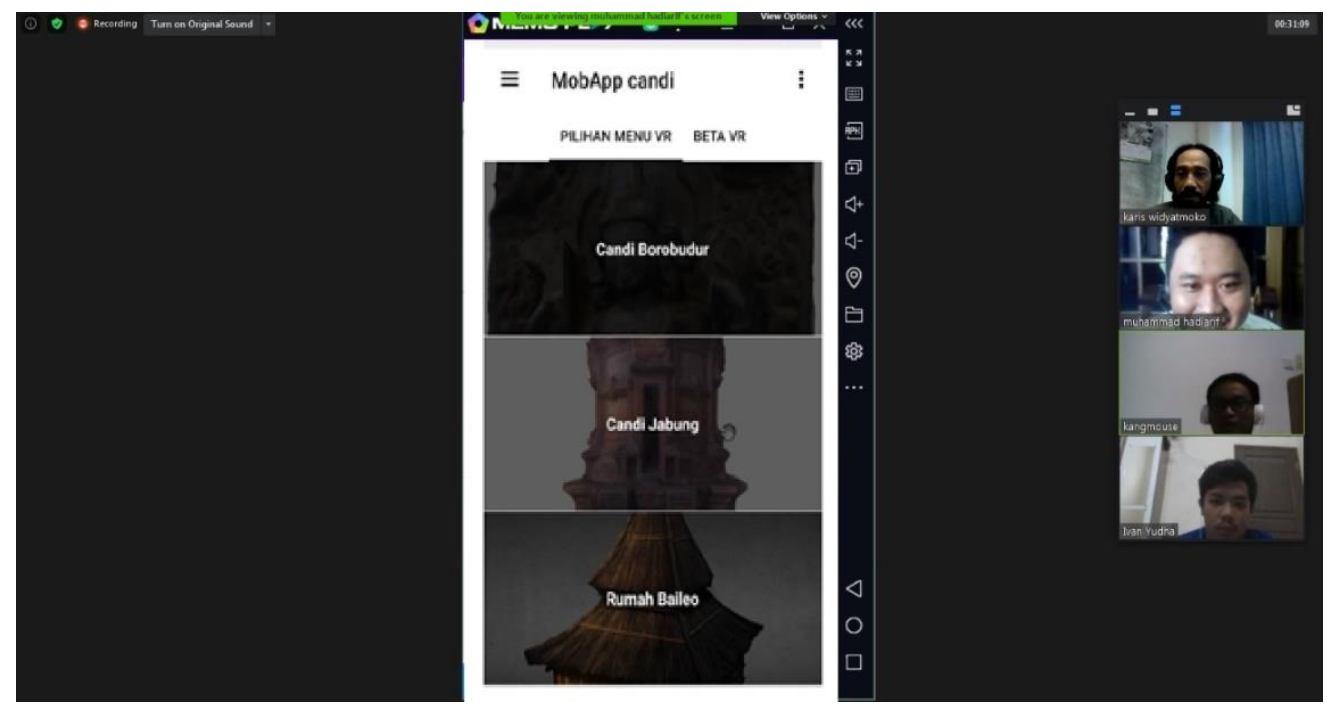

Gambar 10. Pengujian aplikasi yang diikuti guru dan siswa siswa kelas IV SD Patemon 02

[Sumber : Dokumentasi penulis, 2020] 


\subsection{Implementasi Sistem Mobile Aplikasi untuk Sejarah Candi pada Guru (Admin)} Tampilan dari pengelola (admin) mempunyai beberapa fitur yang dapat digunakan untuk mengelola aplikasi pembelajaran, yaitu :

a. Mengelola User

Dari menu tampilan ini, admin dapat mengelola user seperti membuat login user baru, menghapus dan kontrol user

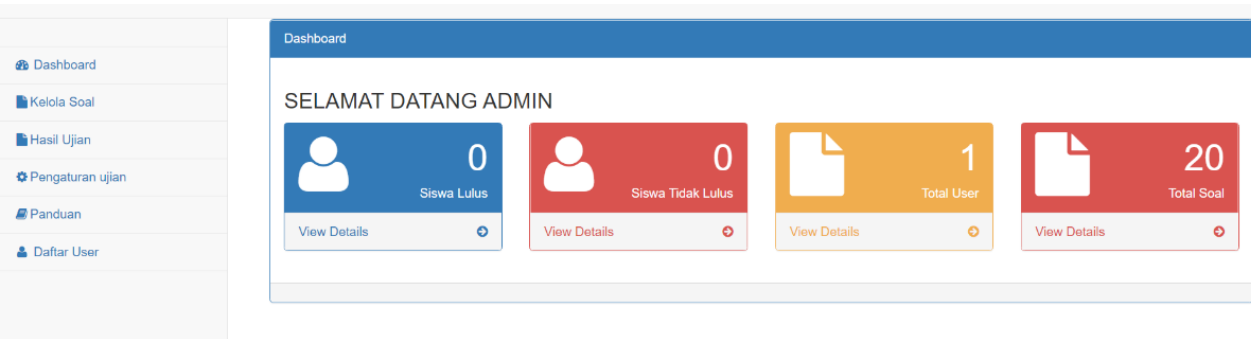

Gambar 10. Tampilan halaman admin

[Sumber : Dokumentasi penulis, 2020]

b. Mengelola Ujian; dapat melihat siswa yang melakukan latihan soal, siapa yang lulus dan tidak serta melihat user yang aktif

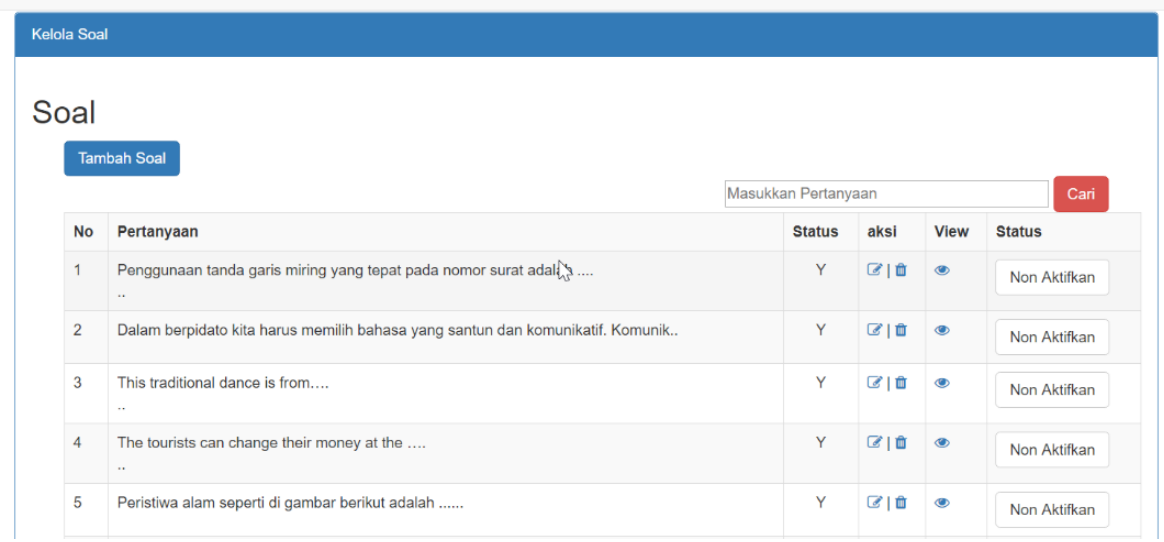

Gambar 11. Tampilan halaman pengelolaan soal

[Sumber : Dokumentasi penulis, 2020]

c. Mengelola Soal, admin dapat memasuka soal dan jawaban yang benar

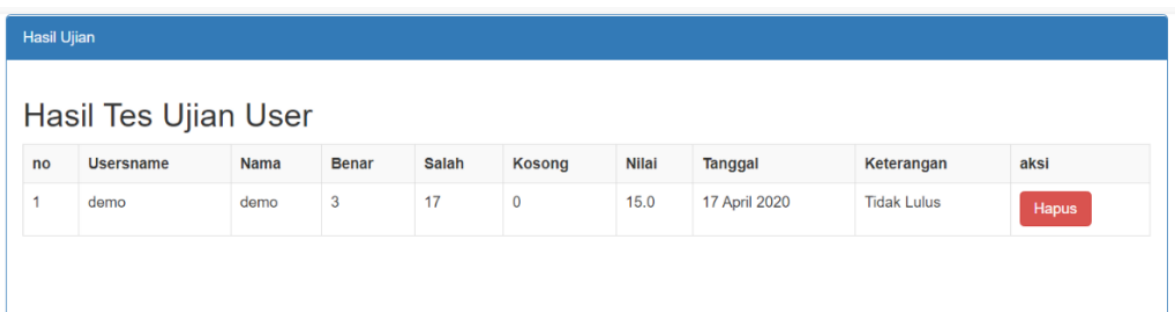

Gambar 12. Tampilan halaman hasil tes ujian

[Sumber : Dokumentasi penulis, 2020] 


\section{KESIMPULAN}

Media pembelajaran virtual reality mengenal candi yang dikembangan dengan metode pengembangan metode software Development Life Cycle (SDLC) yang dikenal dengan nama waterfall system sudah dapat diselesaikan dengan tujuan dapat membatu siswa sebagai user dan guru sebagai admin dalam belajar materi pelajaran IPS kelas IV dengan mudah, menyenangkan, dan interaktif. Hasil ini tercermin dalam hasil testing yang sesuai dengan tujuan perancangan ini. Teknologi virtual reality 3 dimensi digunakan untuk menggambarkan relief candi yang disimulasikan mempermudah pemahaman kepada siswa. Siswa merasa materi yang disampaikan menjadi lebih jelas dan menyenangkan. Mereka dapat melihat bentuk candi secara lebih nyata.

Dari pihak guru juga merasa terbantu dengan aplikasi yang dihasilkan. Guru dapat mengontrol materi yang diberikan kepada siswa dengan lebih baik lagi. Pada tahapan metode yang dipakai yaitu waterfall adalah requirements analysis and definition, system and software design, integration and system testing, operation and maintenance, kelima tahapan tersebut yang membutuhkan waktu paling lama adalah system and software design karena dalam memodelkan karakter candi dan teknologi deteksi kamera sebagai input virtual reallity butuh spesifik dalam pengerjaannya. Pada perkembangan teknologi yang mengacu pada Revolusi Indsutri 4.0, untuk penelitian yang berikutnya diharapkan dapat menambahkan hal-hal yang lebih menarik seperti detail dan relief lebih lengkap dan dapat dikoneksikan dengan industri yang akan memakai aplkasi ini, seperti UPTD di daerah-daerah.

\section{DAFTAR PUSTAKA}

Alfian, M. (2011). Pendidikan Sejarah dan Permasalahan yang dihadapi. Khazanah Pendidikan, 3(2).

Barkah, M. A., \& Agustina, R. (2017). Pemanfaatan Augmented Reality (AR) Sebagai Media Pembelajaran Interaktif Pengenalan Candi - Candi Di Malang Raya Berbasis Mobile Android. Bimasakti : Jurnal Mahasiswa Fakultas Sains Dan Teknologi, 1(5), 1-6.

Dwanoko, Y. S. (2016). Implementasi Software Development Life Cycle (SDLC) Dalam Penerapan Pembangunan Aplikasi Perangkat Lunak. Teknologi Informasi: Teori, Konsep, Dan Implementasi: Jurnal IImiah, 7(2), 83-94.

Kebudayaan, K. P. dan. (2014). Indahnya Kebersamaan, Seri Pembelajaran Tematik Terpadu Untuk SD/MI Kelas IV. Jakarta: Kementerian Pendidikan dan Kebudayaan.

Nana, N., \& Surahman, E. (2019). Pengembangan Inovasi Pembelajaran Digital Menggunakan Model Blended POE2WE di Era Revolusi Industri 4.0. SNFA (Seminar Nasional Fisika Dan Aplikasinya), 82-90.

Pane, S. F., Zamzam, M., \& Fadillah, M. D. (2020). Membangun Aplikasi Peminjaman Jurnal Menggunakan Aplikasi Oracle Apex Online. Bandung: Kreatif Industri Nusantara.

Purwanta, H. (2019). Hakekat Pendidikan Sejarah. Surakarta: UNS Press dan Chers. 
Rizkinaswara, L. (2020). Revolusi Industri 4.0. Retrieved from Direktorat Jenderal Aplikasi Informatika, Kementerian Komunikasi dan Informatika Republik Indonesia website: https://aptika.kominfo.go.id/profil/sejarah-ditjen-aptika/

Sugiarti, H. (2017). Keefektifan Media Pop Up Candi Berbantu Model Snowball Throwing Terhadap Pembelajaran IImu Pengetahuan Sosial Kelas V SDN Kembangarum 02 Mranggen. Pendas Mahakam: Jurnal Pendidikan Dasar, 2(1), 67-71.

Sutoyo, S., \& Agung, L. (2009). Ilmu Pengetahuan Sosial 4 Untuk Kelas 4 SD dan MI. Jakarta: Pusat Perbukuan Departemen Pendidikan Nasional.

Yuhefizar, Y., Mooduto, H. A., \& Hidayat, R. (2009). CMM Website Interaktif MCMS Joomla (CMS). Jakarta: Elex Media Komputindo. 